Article

\title{
That Which Was Ecstasy Shall Become Daily Bread
}

\author{
Barry M. Andrews
}

Unitarian Universalist Congregation at Shelter Rock, 719 Daylily Lane, Bainbridge Island, WA 98110, USA; revbma@aol.com

Academic Editors: Daniel Koch and Kenneth S. Sacks

Received: 26 January 2017; Accepted: 12 April 2017; Published: 24 April 2017

\begin{abstract}
This paper attempts to answer three questions: (1) Was Emerson a mystic? (2) If so, what is the nature of his mysticism? (3) How has his understanding of mysticism influenced by Unitarian theology and spiritual practice? In doing so, it draws upon historical and contemporary studies of mysticism and mystical experience, including those of William James, Leigh Eric Schmidt, and Bernard McGinn among others; the writings of Emerson, including his essays, lectures, and journals, and, finally, the testimonies of his contemporaries and succeeding generations of Unitarian religious leaders. Answering the first question in the affirmative, the paper examines Emerson's understanding of mysticism as a departure from a devotional form of mysticism focused on relationship with a personalized deity and toward a naturalistic, transpersonal type of mysticism, and traces its influence within the context of Unitarian history.
\end{abstract}

Keywords: mysticism; experience; Emerson; Transcendentalism; Unitarianism

Anyone presuming to write on the subject of mysticism would do well to heed this word of caution from writer Kathleen Norris:

The word "mystic" is as dangerous as the word "poet," if only because both words are so vulnerable to misunderstanding and abuse. When we describe someone as a "poet" or a "mystic," we generally mean it as a warning-here's someone whose head is in the clouds and who can't get places on time. Someone we admire, or profess to admire, if we hold a romantic, sentimental view of either poetry or religion. But we wouldn't want our child to marry one, let alone become one (Norris 1998, p. 284).

Clearly, mysticism has been interpreted in various ways, not all of them favorable. The meaning of the term has also changed over time, as noted by Leigh Eric Schmidt in his essay, "The Making of Modern 'Mysticism'" (Schmidt 2003). Thus the question as to whether or not Ralph Waldo Emerson was a mystic hinges on our understanding of the nature of mysticism and mystical experience. Many in his day and since have argued that he was. Others, including Patrick F. Quinn, have insisted that he was not.

Noting the elasticity of the term, Quinn, in "Emerson and Mysticism", attempts to identify "the essentials of mysticism" and then to examine Emerson against these criteria. Mystics, he contends, are known first of all by their way of life. Mystics, "whether European or Oriental, dedicated their lives to a discipline, a mystical program". Secondly, mysticism is a type of religious experience, essentially the same regardless of time and place. In particular, it is an experience of union with God. Thirdly, Quinn states that "mysticism is not a random occurrence", but results from adhering to a spiritual practice. Finally, the mystic "is not immediately concerned about the world, creatures, or human affairs", but is focused instead on a supernatural reality that is distinct from normal, everyday reality. In sum, he holds that "mysticism is the special kind of religious experience which is undergone by a person who has become deeply aware of, and in love with, an objective spiritual reality-usually conceived of 
in the West as God-and who actively engages in the disciplines by which he attains, or believes he attains, union with God" (Quinn 1950).

Measured against these criteria, Quinn finds claims that Emerson was a mystic are unwarranted. Emerson often associated mysticism with alchemy and hermetic thought. He seemed to be unfamiliar with the great mystics of history. Citing the well-known "transparent eye-ball" passage in Nature, Quinn notes that mystics find it difficult to describe their mystical experiences, whereas Emerson apparently does not. Moreover, for Emerson God is not transcendent, but immanent. Having advanced an essentialist argument, Quinn concludes that Emerson is not a mystic, but rather a humanist who "asks us to take all the sense of holiness and reverence that is traditionally reserved for a divine being and to transfer it to the plane of the natural and the human" (Quinn 1950, p. 413).

Add to Quinn's analysis the fact that Emerson never called himself a mystic, and one wonders why anyone today should persist in thinking he was one. But the problem with this conclusion is that Quinn's definition of mysticism, written in 1950, is not only essentialist, but also outdated. Contemporary scholarship is more focused on the inner experience of the mystic than the outward forms that mysticism takes. For example, Bernard McGinn writes, "the mystics invite us to imagine and even to explore an inner transformation of the self, based on a new understanding of the human relation to God. For some mystics this understanding is rooted in extraordinary forms of consciousness, such as visions and ecstasies...Other mystics, however, insist that such special experiences are only preparatory and peripheral, and perhaps even harmful if one confuses them with the core of mysticism understood as inner transformation." (McGinn 2006, p. xiii) Emerson's idea of God differs considerably from the Christian notion. But he too stressed the importance of inner transformation resulting from a new understanding of the individual's relation to the universal Soul revealed in ecstatic experiences. It is this emphasis on inner transformation, rather than the formal criteria Quinn outlines that qualifies Emerson as a mystic.

Historically speaking, the Transcendentalists reinterpreted the nature of mysticism as it was known in their day and made it the basis of religion and spirituality. In the 18th century the word mysticism had primarily negative connotations and was used, pejoratively, to denote false religion, characterized by fanaticism and extravagance rather than calm rationality. In instances where mystics were accorded more positive treatment- the 1797 edition of the Encyclopedia Britannica, for example — they were seen as belonging to a minor sect within Christianity. In the popular mind, mysticism was identified with cults and secret societies. As late as 1847, the author of the book, Mysticism and Its Results, defined mysticism as "the revelation of learning, social, religious, and political, the teaching of which has been, and is, preserved secret from the world, by societies, associations, and confraternities" (Delafield 1847, p. 15).

Schmidt contends that a fundamental shift in the understanding of mysticism took place during the 1840s and 1850s, largely within the context of Unitarianism. The Unitarians had come into prominence in the early nineteenth-century in reaction to Calvinist theology and the religious revivals of the Second Great Awakening. They advocated the use of reason in examining theology and scripture and were averse to the emotional fervor of revivalism. However, a younger generation of Unitarians, influenced by Romantic ideas coming from Britain and Europe, gave new currency to the notion of mysticism. Beginning in 1836, a number of young Unitarian ministers and intellectuals began to meet to discuss the "new views" from across the Atlantic and the shortcomings of the Unitarian church. The members of this group, which came to be called the Transcendentalist Club, included Ralph Waldo Emerson, Theodore Parker, Margaret Fuller, Henry David Thoreau, George Ripley, Elizabeth Palmer Peabody, Frederick Henry Hedge, Bronson Alcott, and a number of others-forty to fifty in all.

Romanticism represented "a crack in nature", Emerson said in the introduction to his 1839 lecture series on "The Present Age", a schism running under literature, philosophy, the church, and the state. "It seems a war betwixt the Intellect and the Affection" (Emerson 1961-1972, vol. 3, p. 187). The impact of Romanticism on the Unitarian church was of paramount concern to the members of the Transcendental Club. Unitarian theology was based on the empirical philosophy of John Locke, which held that knowledge is gained by means of sensory data coming into the mind from the outside world. 
But the Transcendentalists felt strongly that Unitarianism could not be defended on empirical grounds. The Unitarians believed, for instance, that the divine authority of Jesus was confirmed by the miracles he performed. Not only had David Hume argued that miracles were a violation of nature but also German biblical criticism had shown that the Bible was an unreliable source of information.

The Romantic writers-Thomas Carlyle and Samuel Taylor Coleridge, in particular-offered the Transcendentalists an alternative both to the hyper-rationalism and logical inconsistency of Unitarian theology. To persist in grounding faith in the Bible and church doctrine could only lead to skepticism. Emerson made this quite clear in his controversial address at the Harvard Divinity School in 1838. It was an attack on historical Christianity. Speaking to an audience of ministerial students and Unitarian divines, Emerson declared, "whilst the doors of the temple stand open, night and day, before every man, and the oracles of this truth cease never, it is guarded by one stern condition; this, namely, It is an intuition. It cannot be received at second hand". Forsaking this truth, the church had fallen into error. Scripture, ritual, and the teachings of the church had usurped "the place of the doctrine of the soul". As for miracles attesting to the divinity of Christ, he thought the notion monstrous: "It is not one with the blowing clover and the falling rain". The "famine in our churches", he observed, resulted from the fact that "no doctrine of the Reason...will bear to be taught by the Understanding" (Emerson 1971-2013, vol. 1, pp. 80-85).

This distinction between the Reason and the Understanding came from Emerson's reading of Coleridge. In his book, Aids to Reflection, Coleridge asserted that there are two ways of knowing, which he termed the Understanding and the Reason. Understanding, or empirical knowledge, is analytical in nature. Reason, on the other hand, is holistic and intuitive. It is a revelation of the Universal Mind. In a lengthy section of his journal in 1835, which he titled, "Of the Nature of the Mind", Emerson explored the implications of this distinction. The ideas of Reason, he wrote, "astonish the Understanding and seem to it gleams of a world in which we do not live". As with Coleridge, Emerson considered Reason to be the superior way of knowing. "Its attributes are Eternity and Intuition", he asserted. "We belong to it, not it to us". On the other hand, "the Understanding is the executive faculty, the hand of the mind. It mediates between the soul and inert matter. It works in time and space, and therefore successively. It divides, compares, reasons, invents. It lives from the Reason, yet disobeys it. It commands the material world, yet often for the pleasure of the sense" (Emerson 1960-1982, vol. 5, pp. 270-72).

It would appear that in the materialistic world-view of empirical philosophy, the Understanding has gained the upper hand, to the neglect and disadvantage of the Reason. In living "for the pleasure of the sense", people live superficial, one-dimensional lives in which appearances count for everything. "We walk about in a sleep", Emerson continued. "A few moments in the year or in our lifetime we truly live; we are at the top of our being; we are pervaded, yea, dissolved by the Mind: but we fall back again presently". Thus, he was led to ponder one of the perennial quandaries of the spiritual life:

We stand on the edge of all that is great yet are restrained in inactivity and unacquaintance with our powers...We are always on the brink of an ocean into which we do not yet swim...We are in the precincts, never admitted. There is much preparation-great ado of machinery, plans of life, travelling, studies, profession, solitude, often with little fruit. But suddenly in any place, in the street, in the chamber, will the heaven open, and the regions of wisdom be uncovered, as if to show how thin the veil, how null the circumstances. As quickly, a Lethean stream washes through us and bereaves us of ourselves.

What a benefit if a rule could be given whereby the mind, dreaming amidst the gross fogs of matter, could at any moment east itself and find the sun. But the common life is an endless succession of phantasms. And long after we have deemed ourselves recovered and sound, light breaks in upon us and we find we have yet had no sane hour (Emerson 1960-1982, vol. 5, pp. 274-75). 
Emerson was drawn to Coleridge's ideas because he found in them a more accurate depiction of the way the mind works than the empirical epistemology of John Locke. He did not deny the importance of the Understanding. The realm of the Understanding was subordinate to that of the Reason, not divorced from it. The affairs of daily life should be guided by spiritual and moral considerations, not solely by material or instrumental ones. Unfortunately, it is the Understanding that is our default mode of encountering the world. The revelations of Reason, as noted in the passage above, come to us only intermittently and largely unannounced. So seldom is their occurrence and so at odds with our empirical experience, we are tempted to discount their validity. Yet those ecstatic experiences represent the spiritual high points of our lives.

Emerson's high estimation of Coleridge was widely shared among the members of the Transcendentalist circle. They found in Coleridge and other Romantic writers a response to the troubling skepticism engendered by Hume and the Enlightenment assault on the grounds of religious belief. In his study of The Romantic Foundations of the American Renaissance, Leon Chai argues that in the face of such attacks "it was necessary to find the source of religion within consciousness itself, as the one undeniable Cartesian datum: to create out of the epiphanic experience of consciousness a sense of the sublime and infinite, a new content of religious awareness" (Chai 1987, p. 10). It was this fundamental shift-from establishing religious belief on the basis of scripture and doctrine to locating it in human consciousness-that constituted the "crack in nature" Emerson had proclaimed. As a consequence, the epistemology of religious experience shifted also, from empirical ways of knowing to intuitive and, I would argue, essentially mystical ones.

In a lecture on "Religion" in the "Philosophy of History" lecture series given in the winter of 1836-1837, Emerson attempted to describe the nature of these revelations of the Reason, even though "the extreme simplicity" of these intuitions "embarrasses every attempt at analysis". They are characterized, first of all, by their universality. They are revelations of the Universal Mind, common to all individual human beings. Secondly, they are moral in the sense that they prompt us to right action. And, third, they elevate those who experience them. The experience itself "is an influx of the Divine Mind into our mind. It is an ebb of the Individual rivulet before the flowing surges of the Sea of Life". This experience - which can only be described as a mystical experience-is at the heart of all religions and common to all people:

To this Soul, this Reason, every human being has access. And every moment when the individual feels himself interpenetrated by it, is memorable. Always, I believe, by the necessity of our constitution, a certain enthusiasm attends the individual's consciousness of that divine presence. The character and duration of this enthusiasm varies with the state of the individual from an extasy [sic] and trance and prophetic inspiration,-which is its rarer appearance,- - to the faintest glow of virtuous emotion, in which form it warms, like our household fires, all the families and associations of men, and makes society possible.

Unfortunately, "the Understanding strives to write out the whole vision in a Confession of Faith", with the result that "Deity becomes more objective until finally flat idolatry appears". This is what has happened in Christendom. "Its established churches have become old and ossified under the accumulation of creeds and usages" (Emerson 1961-1972, vol. 2, pp. 86-87, 89-90, 96-97). Yet skepticism is not inevitable. The Reason has a way of finding expression, no matter how much it becomes distorted by the Understanding.

In this early lecture of Emerson's we begin to see the reinvention of mysticism that Schmidt describes in his essay. Most importantly, the mystical experience is not restricted to a special class of persons focused on a supernatural reality distinct from normal, everyday reality. The revelations of the Universal Mind are available to all persons by virtue of the fact that there is "one Mind common to all individual men" (Emerson 1960-1982, vol. 5, p. 222). Nor is the mystical experience exceptional. It occurs along a continuum from "an extasy...to the faintest glow of virtuous emotion". Furthermore, the Universal Mind is not transcendent, but immanent. "As long as the soul seeks an external God", he wrote in his journal, "it never can have peace, it always must be uncertain what may be done and 
what may become of it. But when it sees the Great God far within its own nature, then it sees that always itself is a party to all that can be, that always it will be informed of that which will happen and therefore it is pervaded with a great Peace"(Emerson 1960-1982, vol. 5, p. 223). For Emerson, God is not personal, but impersonal, and therefore is not to be found without, in some supernatural realm, but rather within, in human consciousness itself.

In his first book, Nature, Emerson described an ecstatic experience he once had crossing the Boston Common at twilight:

Standing on the bare ground,-my head bathed by the blithe air, and uplifted into infinite space,-all mean egotism vanishes. I become a transparent eyeball. I am nothing. I see all. The currents of the Universal Being circulate through me; I am part or particle of God. The name of the nearest friend sounds then foreign and accidental. To be brothers, to be acquaintances,--master or servant, is then a trifle and a disturbance. I am the lover of uncontained and immortal beauty (Emerson 1971-2013, vol. 1, p. 10).

This passage has attracted much attention, not all of it favorable. It was caricatured by fellow Transcendentalist, Christopher Pearse Cranch, in a sketch depicting Emerson the mystic as a long-legged eyeball. Some critics have found the description awkward and inauthentic. Patrick Quinn, as noted earlier, views the passage as evidence that Emerson was not a mystic on the grounds that the mystical experience is ineffable and therefore cannot be described, as Emerson has attempted to do. These criticisms notwithstanding, the passage has all the earmarks of what William James finds characteristic of mystical experiences.

In his classic work on The Varieties of Religious Experience, James notes four attributes of mystic states. The first of these is ineffability. They cannot be adequately described because they are subjective states, more akin to feeling than intellect. Secondly, they have a noetic quality. "They are states of insight into depths of truth unplumbed by the discursive intellect. They are illuminations, revelations, full of significance and importance, all inarticulate though they remain; and as a rule they carry with them a curious sense of authority for after-time". The third characteristic is that such states are transient. They are generally brief and cannot be sustained for very long periods of time. Finally, according to James, "the mystic feels as if his own will were in abeyance, and indeed sometimes as if he were grasped and held by a superior power" (James 1925, pp. 380-81).

In the description of his experience on the Boston Common, Emerson tells us where it occurred and what it felt like. Ecstasy is his favorite name for such experiences, a word that means to stand outside of one's self. This passage is a good case in point. Emerson loses his sense of self and feels alienated from others and his surroundings. He experiences a sense of elevation and of being pervaded by the "currents of the Universal Being". Clearly, he feels moved by the experience and finds it deeply meaningful. As Emerson would say, it is a revelation of the Reason, not of the Understanding. As such it calls into question the validity of everyday experience. We don't know the duration of the experience, though apparently it didn't last long. Finally, it is evident from his description that Emerson felt he was a passive recipient of what transpired in his walk across the common.

As we have seen, Quinn uses the passage to show that Emerson describes an experience that is held to be ineffable. But the point about ineffability is not simply that mystical experiences are difficult to describe, but, more importantly, that they are, as James points out, subjective in nature. Emerson's account is clearly subjective. Another question to consider is whether or not Emerson had other experiences of the same kind. Was this experience an example of what Arthur Versluis, in his book, American Gurus: From Transcendentalism to New Age Religion, calls "immediatism"? Immediatism, Versluis writes, is "a claim that one can achieve enlightenment or spiritual illumination spontaneously, without any particular means, often without meditation or years of guided praxis" (Versluis 2014, p. 2).

Versluis points to the same passage in Nature to show that Emerson's mysticism is esoteric in the sense that it is open only to a few, and that the experience he had on the common occurred spontaneously and not as the result of any preparation on his part. As to whether or not Emerson's mysticism is 
esoteric, I would note, first of all, that Emerson himself did not think so. In "Inspiration", one of his later essays, he wrote, "I hold that ecstasy will be found normal, or only an example on a higher plane of the same gentle gravitation by which stones fall and rivers run" (Emerson 1971-2013, vol. 8, p. 153). That is to say, ecstasy is not only normal but also natural. And, as we have seen in his lecture on religion, "every human being has access" to the revelations of the Universal Mind. In a letter to a friend, William James wrote, "I attach the mystical or religious consciousness to the possession of an extended subliminal self with a thin partition through which messages make interruption. We are thus made convincingly aware of the presence of a sphere of life larger and more powerful than our usual consciousness, with which the latter is nevertheless continuous" (Richardson and James 2006, p. 406). Like Emerson, James felt that everyone was capable of having a mystical experience even if, as James suggests, for some people the "messages" failed to penetrate that "thin partition". Thus I would argue that there is nothing esoteric about such experiences. They are natural even if they are not common or ordinary, and many people have had them to some degree.

It is impossible to say how many such experiences Emerson may have had, how often, or to what degree. The experience on the Boston Common may have been unique in its intensity, but it would be a mistake to believe he had no acquaintance with such experiences either before or after. ${ }^{1}$ His journals, lectures, and essays are replete with references to ecstasies. In the essays alone there are at least thirty-six of them. ${ }^{2}$ More importantly, Emerson was preoccupied, from the beginning to the end of his career, with developing a means of gaining access to such illuminations. As early as 1832 he noted in his journal a desire to develop practices "to solicit the soul":

How hard to command the soul or to solicit the soul. Many of our actions, many of mine are done to solicit the soul. Put away your flesh, put on your faculties. I would think-I would feel. I would be the vehicle of that divine principle that lurks within and of which life has afforded only glimpses enough to assure me of its being. We know little of its laws-but we have observed that a north wind clear cold with its scattered fleet of drifting clouds braced the body and seemed to reflect a similar abyss of spiritual heaven between clouds in our minds; or a brisk conversation moved this mighty deep or a word in a book was made an omen of by the mind and surcharged with meaning or an oration or a south wind or a college or a cloudy lonely walk...And having this experience, we strive to avail ourselves of it and propitiate the divine inmate to speak to us again out of clouds and darkness. Truly whilst it speaketh not, man is a pitiful being. He whistles, eats, sleeps, gets his gun, makes his bargain, lounges, sins, and when all is done is yet wretched. Let the soul speak, and all this drivelling and these toys are thrown aside and man listens like a child (Emerson 1960-1982, vol. 4, p. 28-29).

He seems to suggest that a conversation, a book, or a "cloudy lonely walk" might prepare the mind for the reception of the "divine principle that lurks within". Is the reference to the "cloudy lonely walk" perhaps a foreshadowing of his experience crossing the common?

Contrary to Versluis's contention that Emerson, as an example of "immediatism", engaged in no spiritual practice, there is considerable evidence that, in fact, he did. In reinventing mysticism, Emerson also developed, through a process of experimentation, a discipline designed (though not guaranteed) to "solicit the soul". It is in this respect that he advances beyond the Romantic poets, such as Wordsworth, who lamented the demise of the ecstasies of youth. The question for Emerson was, if religious truth is based in human consciousness and revealed in moments of epiphanic experience, as the Romantics asserted, then how, if at all, can these revelations be summoned and sustained? Implicit

\footnotetext{
Another one is described in a journal entry made on 11 April, 1834. (Emerson 1960-1982, vol. 4, p. 272-73)

According to the Concordance to the Collected Essays of Ralph Waldo Emerson. Compiled by Eugene F. Irey. (Irey n.d.) Available online: http://concordlibrary.org/special-collections/emerson-concordance/ (accessed on 20 April 2017).
} 
in this question is the irony or paradox faced by every mystic; namely, if the experience comes by way of surrender, then how can one actively summon it?

Emerson's first sustained effort to outline a spiritual practice came in a series of lectures on "Human Culture" given in the winter of 1837-1838. The word culture was used in the sense of cultivation rather than refinement. As Emerson expressed it, "Culture in the high sense does not consist in polishing and varnishing, but in so presenting the attractions of nature that the slumbering attributes of man may burst their sleep and rush into the day" (Emerson 1961-1972, vol. 2, p. 216). Culture is the process of awakening these slumbering attributes to the Ideal, which is "the presence of the universal mind to the particular". The means of Culture, he said, "is the related nature of man" (Emerson 1961-1972, vol. 2, p. 220). That is to say, human beings are part and parcel of the natural world. We have become estranged from this world and we must restore our relationship with it. Nature, he advised, will be our teacher and guide.

The possibility of achieving enlightenment is predicated on a program for spiritual growth. For Emerson and the Transcendentalists, self-culture is the term they used for the practices they employed to this end. Realizing a kinship with nature is a prerequisite of Emerson's program of self-culture. "We need Nature, and the cities give the human senses not room enough. The habit of feeding the senses daily and nightly with the open air and firmament, presently becomes so strong that we feel the want of it like water for washing" (Emerson 1961-1972, vol. 2, p. 275). A second prerequisite of self-culture is self-reliance. Our education is too much aimed at conformity. We should put off imitation as child's clothes and assume our own vows, Emerson said. "[I]nstead of following with a mendicant admiration the great names that are inscribed on the halls of memory, let [the student] know that they are only marks and memoranda for his guidance...Let him know that the stars shone as benignantly on the hour of his advent as on any Milton or Washington or Howard" (Emerson 1961-1972, vol. 2, p. 228). There is thus no enlightenment by proxy. It cannot be gained at second hand, but only by trusting our own intuition.

In discussing the culture of the intellect, Emerson made the familiar distinction between Reason and Understanding, or between intuitive and empirical ways of knowing. Reason is superior to Understanding, since it is by way of Reason that the individual mind receives the influx of the Divine Soul. Spiritual growth, he insisted, consists in abandoning one's self to Instinct, or intuition. "True growth is spontaneous in every step. The mind that grows could not predict the times, the means, the mode of that spontaneity. God comes in by a private door into every individual: thoughts enter by passages which the individual never left open". This observation raises, once again, the paradox of the mystical life. We seek enlightenment but cannot find it. It is only when we cease from striving that it comes to us. But it appears that the striving was an important part of the process. "But the oracle comes because we had previously laid siege to the shrine. It seems as if the law of the Intellect resembled that great law of Nature by which we now inspire, then expire the breath; by which the heart now draws in, now hurls out the blood,- - the law of undulation. So now you must labor with your brains, and now you must forbear your activity and see what the Great Soul showeth" (Emerson 1961-1972, vol. 2, pp. 250, 252).

Emerson offered his auditors two practical methods for laying siege to the shrine. The first was solitude. "In your arrangements for your residence see that you have a chamber for yourself, though you will sell your coat and wear a blanket". The second was keeping a journal. "Pay so much honor to the visits of Truth to your mind as to record those thoughts that have shown therein". Of the two, solitude was especially important:

The simple habit of sitting alone occasionally to explore what facts of moment lie in the memory may have the effect in some more favored hour to open to the student the kingdom of spiritual nature. He may become aware that around him roll new at this moment and inexhaustible the waters of Life; that the world he has lived in so heedless, so gross, is illuminated with meaning, that every fact is magical; every atom alive, and he is the heir of it all (Emerson 1961-1972, vol. 2, p. 261). 
In the course of his lecturing and writing, Emerson added to this list of spiritual practices. In addition to solitude and journal writing, his regimen included contemplation, conversation, reading, walking, and plain living. We also know that he found inspiration in the religious texts of the near and far East. In the late essay, "Inspiration", mentioned earlier, he returned to the theme of illumination and the means of achieving it. Nothing great or lasting can be accomplished without inspiration, but such insights are only occasional and brief. It comes to some but once in their life. "But what we want is consecutiveness", he wrote. "Tis with us a flash of light, then a long darkness, then a flash again". Too soon we return to the mundane preoccupations of everyday life:

This insecurity of possession, this quick ebb of power,- -as if life were a thunder-storm wherein you can see by a flash the horizon, and then cannot see your hand-tantalizes us. We cannot make the inspiration consecutive. A glimpse, a point of view that by its brightness excludes the purview, is granted, but no panorama. A fuller inspiration should cause the point to flow and become a line, should bend the line and complete the circle (Emerson 1971-2013, vol. 8, p. 152).

Are such moods within our control? He wondered. If only we knew how to summon them. Noting that "in the experience of meditative men there is a certain agreement as to the conditions of reception", he went on to list a number of practices conducive to the reception of inspiration. Perhaps in light of his advancing age, Emerson noted, first of all, the importance of health, exercise, rest, and willpower as necessary conditions. He went on to identify several practices he has found to be efficacious. Like his younger friend, Henry David Thoreau, he advised readers to rise early every day and "defend your morning" against unnecessary intrusions. He continued to find periods of solitude and walks in nature essential to inspiration. Certain locales, such as mountain-tops, the sea shore, and rivers and brooks may also stimulate the imagination. Conversation, at its best, he noted, "is a series of intoxications":

In enlarged conversation we have suggestions that require new ways of living, new books, new men, new arts and sciences. By sympathy, each opens to the eloquence and begins to see with the eyes of his mind. We were all lonely, thoughtless; and now a principle appears to all: we see new relations, many truths; every mind seizes them as they pass; each catches by the mane one of these strong coursers like horses of the prairie, and rides up and down in the word of the intellect.

Finally, he recommended reading poetry and the classics as sources of insight and inspiration. He ended the essay with a couple of lines from The Excursion by Wordsworth, which he quoted a number of times in his journals over the years:

"'Tis the most difficult of tasks to keep

Heights which the soul is competent to gain".

Though rare and fleeting, and difficult to achieve, moments of illumination are the source and substance of spiritual truth for us (Emerson 1971-2013, vol. 8, pp. 156-66).

What, we may ask, was the point of these heights he sought to gain? What did he hope to achieve? The answer to these questions reveals additional ways in which Emerson's understanding of mysticism differed from more traditional ones. The traditional answer to these questions is union with God in the supernatural sense of the word. Most mysticism is devotional in this respect.

Henry Ware, Jr. was a former ministerial colleague of Emerson's at Boston's Second Church. He left Second Church for a position on the Harvard Divinity School faculty. He was a deeply spiritual person, and tolerant- to a point-of the views of those in the Transcendentalist circle. In an article on "The Mystical Element in Religion", written for the Christian Examiner, a Unitarian periodical, in 1844, Ware offered a sympathetic view of mysticism from a Unitarian perspective. Mysticism had progressed from being a form of fetishism to a veneration of doctrine. With the advance of reason 
we have reached the third stage of mysticism, not of outward objects or dogmatic mysteries, but of religious experience. "We have used the word mysticism in a wider than its usual signification, but what is mysticism but the striving of the soul after God, the longing of the finite for communion with the Infinite? And this the mind has sought in outward nature, in abstract speculation and doctrine, and in the depths of inward experience and the quiet of lonely contemplation". The last, he wrote, is the only true form of mysticism. Although we may commune with God "through outward nature and our understanding, it is only through our affections and, and by virtue of spiritual alliance with him, that we can know anything of him with assurance". At its best, mysticism cherishes faith, sanctifies nature, and "brings the soul near to God" (Ware 1844, p. 308ff.).

Ware's view of mysticism is a liberal Unitarian one, and was shared even by many of the Transcendentalists. It is enlightened and non-sectarian, but it is also devotional in that it envisions communion with a transcendent, supernatural deity, whether approached through nature, worship, or human consciousness. Emerson's understanding of mysticism, on the other hand, is notable for its naturalism. It is not devotional. He does not envision a nearness to God because God is not a being separate from nature or himself. Emerson's cosmology is monistic, not dualistic. Thus, for Emerson God is impersonal, not personal, and immanent in the world, not apart from it. Although he uses the word God, he devises numerous terms and phrases that qualify his sense of it. In his essay, "Circles", for example, God is described as "the Unattainable, the flying Perfect, around which the hands of man can never meet" (Emerson 1971-2013, vol. 2, p. 179). As the title of his most famous essay on the subject suggests, the Over-Soul is his preferred term, derived perhaps from his reading of the Vedas. Even in this essay we encounter a number of synonyms, such as Supreme Critic, Unity, Highest Law, Wisdom, and the like. As for what these terms mean, there is no better definition than the one he gives in the essay:

We live in succession, in division, in parts, in particles. Meantime within man is the soul of the whole; the wise silence; the universal beauty, to which every part and particle is equally related; the eternal One. And this deep power in which we exist, and whose beatitude is all accessible to us, is not only self-sufficing and perfect in every hour, but the act of seeing and the thing seen, the seer and the spectacle, the subject and the object, are one. We see the world piece by piece, as the sun, the moon, the animal, the tree; but the whole, of which these are the shining parts, is the soul (Emerson 1971-2013, vol. 2, p. 160).

Emerson's type of mysticism is distinctive in another respect also. He was familiar with the writings of a number of mystics, including Jacob Boehme, Madame Guyon, and Emanuel Swedenborg. ${ }^{3}$ In these accounts he recognized "a tendency to enthusiasm", or ecstasy, but, thought they "failed by attaching themselves to the Christian symbol, instead of the moral sentiment, which carries innumerable christianities, humanities, divinities in its bosom" (Emerson 1971-2013, vol. 4, p. 55). In an effort to free ecstasy from sectarian associations, he describes it in naturalistic terms as a form of power. Power is a loaded term. Very often it suggests authority or control exerted over others. But in Emerson's usage it means an energy or release of potential that is inherent in nature. "All power is of one kind", he wrote in his essay on "Power", "a sharing of the nature of the world. The mind that is parallel with the laws of nature will be in the current of events, and strong with their strength" (Emerson 1971-2013, vol. 6, p. 30). He first expressed this idea in his 1841 lecture on "The Method of Nature" delivered at Waterville College in Maine. "The method of nature", he said, "who could ever analyze it? That rushing stream will never stop to be observed". His depiction of nature is that of a rushing torrent, always changing and never stopping. It is a work of ecstasy, he insisted: "the spirit and peculiarity of that impression nature makes on us is this, that it does not exist to any one or to any

3 Emerson's library contained Jacob Boehme's Works (4 vols.); Madame Guyon's Opuscules Spirituels and Thomas Upham's Life and Religious Opinions and Experiences of Madame de Lu Mothe Guyon (2 vols.), and sixteen different volumes of Swedenborg's writings. See (Harding 1967). 
number of particular ends, but to numberless and endless benefit, that there is in it no private, no rebel leaf or limb, but the whole is oppressed by one superincumbent tendency, obeys that redundancy or excess of life which in conscious beings we call ecstasy" (Emerson 1971-2013, vol. 1, pp. 124, 126-27).

For Emerson the health of the soul consists in its "being the channel through which heaven flows to earth, in short, in the fullness in which an ecstatical state takes place" therein (Emerson 1971-2013, vol. 1, p. 130). It is for this reason that he is always promoting abandonment and spontaneity. In ecstasy we are one with the course of nature. We feel the energy of the universe flowing through us. One of his favorite metaphors, repeated numerous times in his essays and journals, is "shooting the gulf". It is hard to say where Emerson first encountered the phrase, but it is mentioned in Daniel Defoe's Voyage Round the World (1725) and in Robert Southey's Lives of the British Admirals (1834). As Southey expressed it, "To sail around the world was in the popular belief an adventure of the most formidable kind, and not to be performed by plain sailing, but by reaching the end of this round flat earth, and there shooting the gulf, which is the only passage from one side of the world to the other" (Southey 1834, vol. 3, p. 239). The expression suggests breaking out into something new, or crossing from one plane of existence to another. "Power ceases in the instant of repose", Emerson wrote in "Self-Reliance", "it resides in the moment of transition from a past to a new state, in the shooting of the gulf" (Emerson 1971-2013, vol. 2, p. 40).

Emerson's mysticism differs from traditional models in yet another important respect. He was aware, both from his reading of the mystics and his own personal experience, that ecstatic experiences are both infrequent and brief. And yet they reveal vital truths about nature and human life. He returned to this theme in his 1841 address, "The Transcendentalist". Although delivered as a third-person account, it is clear that he was talking about himself when he said the following:

It is not to be denied that there must be some wide difference between my faith and other faith; and mine is a certain brief experience, which surprised me in the highway or in the market, in some place, at some time,-whether in the body or outs of the body, God knoweth,- -and made me aware that I had played the fool with fools all this time...Well, in the space of an hour, probably, I was let down from this height; I was at my old tricks, the selfish member of a selfish society. My life is superficial, takes no root in the deep world; I ask, When shall I die, and be relieved of the responsibility of seeing an Universe which I do not use? I wish to exchange this flash-of-lightening faith for continuous daylight, this fever-glow for a benign climate (Emerson 1971-2013, vol. 1, p. 213).

Jacob Boehme says that he suffered "many a shrewd Repulse" in his struggle with that "powerful contrarium", common consciousness. Madame Guyon describes frequent periods of alternating light and darkness (Underhill 1911, pp. 307, 458). (In more extreme cases, mystics feel a sense of great loss, a "dark night of the soul", as the experience fades.) For Emerson, the alternation between these two modes of being - ecstatic rapture and everyday life-is an example of the polarity found in nature as a whole. Emerson described this theory in his address on "The American Scholar":

The great principle of Undulation in nature, that shows itself in the inspiring and expiring of the breath; in desire and satiety; in the ebb and flow of the sea, in day and night, in heat and cold, and yet more deeply engrained in every atom and every fluid, is known to us under the name of Polarity,--these "fits of easy transmission and reflection", as Newton called them, are the law of nature because they are the law of spirit (Emerson 1971-2013, vol. 1, p. 61).

While he acknowledged the undulation or alternation of mental states, he sought to achieve a balance in life between moments of illumination and mundane existence. In "The Transcendentalist" the polarity is referred to as double consciousness, two states of thought that stand in wild contrast to one another:

The worst feature of this double consciousness is that the two lives, of the understanding and of the soul, which we lead, really show little relation to each other, never meet and 
measure each other: the one prevails now, all buzz and din; and the other prevails then, all infinitude and paradise; and with the progress of life, the two discover no greater disposition top reconcile themselves. Yet, what is my faith? What am I? What but a thought of serenity and independence, an abode in the deep blue sky? Presently the clouds shut down again; yet we retain the belief that this petty web we weave will at last be overshot and reticulated with veins of the blue, and that moments will characterize the days (Emerson 1971-2013, vol. 1. pp. 213-14).

Although Emerson realized that moments of illumination are few and far between, he found such moments to be of great significance. He also knew that they could not be summoned at will. Nevertheless, he believed that people could improve the odds of their reception through cultivating the soul. This he sought to do by engaging in the spiritual practices of self-culture. He thought that society would be enriched by those who were able to communicate the wisdom gained in such experiences-“"the exciters and monitors; collectors of the heavenly spark with power to convey the electricity to others" (Emerson 1971-2013, vol. 1, p. 216). But he never considered that illumination was reserved for a certain class of persons. In fact, he felt that everyone's life would be elevated through "communication with the spiritual nature". The biggest obstacle is "that the community in which we live will hardly bear to be told that every man should be open to ecstasy or a divine illumination, and his daily walk elevated by intercourse with the spiritual world" (Emerson 1971-2013, vol. 1, p. 145).

This is because daily life is lived on the level of the Understanding and not the Reason. We are accustomed to dealing with the everyday world in a practical, pragmatic way. We get up in the morning and go about our business thinking that this is the only reality there is. Because it is ordered according to the Understanding, society is materialistic and views nature as a resource to be exploited. Empirical ways of knowing predominate over intuitive modes of thought. It is for these reasons that Emerson felt our life, as we live it, is common and mean, and sought to find a proper balance between the realities of everyday life and the demands of the spirit, in the hope that, as put it in his 1840 Dial essay, "Thoughts on Modern Literature", "that which was ecstasy shall become daily bread" (Emerson 1971-2013, vol. 10, p. 120).

Emerson emphasizes the inner transformation that occurs as a result of viewing the world intuitively, through the eye of Reason. In this respect, he has much in common with Christian mystics and mystics of other religions. His mysticism differs from these traditions in that it is this-worldly and potentially accessible to all persons. He freed mysticism from its sectarian and institutional constraints and enabled us to see it as a universal element of human experience. It is hard to imagine, for instance, how William James could have written The Varieties of Religious Experience without the influence of Emerson and the Transcendentalists (Schmidt 2003, p. 284). Leigh Eric Schmidt examines the genesis and development of modern mysticism in Restless Souls: The Making of American Spirituality. Beginning with "the question of Mysticism" as a topic of discussion at a meeting of the Transcendental Club in 1838, Schmidt describes the process by which mysticism came to be seen as a timeless and universal form of religious experience (Schmidt 2005, chapt. 1). Although the process began with the Transcendentalists in the context of New England Unitarianism, Schmidt widens the scope of his survey to show the impact of the modern conception of mysticism on American religious life more broadly.

In this paper I am particularly concerned with tracing Emerson's influence within Transcendentalism and the Unitarian movement. Unitarianism is unusual, if not unique, in its openness to change, due in no small part to the influence of Emerson, who, in his 1838 address to the graduates of the Harvard Divinity School, rejected the primacy of institutions in favor of individual religious experience. "Meantime, whilst the doors of the temple stand open, night and day, before every man, and the oracles of this truth cease never, it is guarded by one stern condition", he said; "this namely, It is an intuition. It cannot be received at second hand...There is no doctrine of the Reason which will bear to be taught by the Understanding" (Emerson 1971-2013, vol. 1, pp. 80-81). The emphasis on individual religious experience, as articulated by Emerson and the Transcendentalists, is a strand that runs throughout the history of Unitarianism 
and accounts for the difficulty the denomination has had in establishing any lasting or binding creedal statement. The use of the term "mysticism" was used by successive generations of Unitarian and Unitarian Universalist religious leaders as a marker of religious experience more or less as Emerson defined it.

One way of following this strand is to look, first of all, to the Transcendentalists themselves. Their renewed interest in mysticism led not only to a redefinition of the term itself but also to a search for exemplary modern mystics. They were inevitably drawn to consider if Emerson himself might be regarded as a case in point. Octavius Brooks Frothingham (1822-1895) was a younger member of the Transcendentalist circle. Trained as a minister, he served congregations in Massachusetts, New Jersey, and New York. His radical views led him to join in the formation of the Free Religious Association, of which he served as president from 1867 to 1878. He wrote biographies of several of the Transcendentalists and a history of the movement, Transcendentalism in New England, in 1876. In "The Mystics and Their Creed", an article written in 1861, he asserted that mysticism is unique "to no sect of believers, to no church, to no religion", but is common to all. "The mystic affirms the existence in man, of a separate faculty, which he calls the intuitive faculty, whose office is to gaze on the pure, abstract and ideal truth" (Frothingham 1861, p. 99ff.). Frothingham nowhere mentions Emerson in the essay, yet he frequently quotes from Emerson's works, without attribution, to illustrate his points.

James Freeman Clarke (1810-1888), a friend of Emerson's and a fellow Transcendentalist, was more explicit on this point. Unlike Emerson, he remained in the ministry and became a respected leader in the Unitarian denomination. Following a long pastorate with the Church of the Disciples in Boston, he taught at Harvard Divinity School. He wrote a chapter on "The Mystics in All Religions", in his 1881 book, Events and Epochs in Religious History. The mystical experience, he said, "is a state of the soul which transcends every act of reason or of faith, in which everything but God loses reality. He who has been in this state retains much of its influence afterward. He sees through the shows of things to their centre, becomes independent of time and space, master of his body and mind, ruler of nature by the sight of her inmost laws, and elevated above all partial religions into the Universal Religion" (Clarke 1881, p. 276). In his survey of mysticism, he named Emerson as one of two American mystics, the other being Jones Very.

The Transcendentalists' influence continued to be felt in the Unitarian denomination after the Civil War. Tensions had arisen in the denomination as it drifted increasingly in the direction of religious naturalism theologically. As the denomination struggled with a sense of identity in changing times, mysticism, in the Transcendentalists' broadened definition of the term, was seen as a central feature of its identity going forward, in spite of the fact that it had aroused such controversy decades earlier. It was seen as a way of threading the needle between contested issues of religious doctrine, on the one hand, and outright skepticism, on the other. Charles Carroll Everett (1829-1900) was not a Transcendentalist. He had been a Unitarian minister before becoming professor and dean of the faculty at Harvard Divinity School. Although his field was New Testament studies, he also lectured on non-Christian religions. In 1874, he published an article on "Mysticism" in The Unitarian Review and Religious Magazine, in which he adopted the broader definition of the term given by Emerson and the Transcendentalists:

The word mysticism, whenever properly used, refers to the fact that all lives, however distinct they may appear, however varied may be their conditions and their ends, are at heart one; that they are the manifestations of a common element; that they all open into this common element and thus into one another...Mysticism is the is the recognition of the universal element in all individual forms...

All the greatest thinkers and seers of the world have been more or less imbued with it. Modern creed makers and creed holders may disown it; but the religious founders, those on whose mighty foundations the creed makers rear their shapeless and unsubstantial fabrics, wrought from the intuition and the inspiration of the mystical view of life (Everett 1874, p. 5ff.). 
Unitarian Historian George Willis Cooke (1848-1923) wrote the first biography of Emerson, Ralph Waldo Emerson: His Life, Writings, and Philosophy, in 1881. He, too, had been a Unitarian minister, serving several congregations in the Midwest. He considered himself a student of Emerson and a Transcendentalist sympathizer. Emerson is a mystic, he asserted, and "is only to be understood when placed in the company of the great mystics of all ages, and his teachings compared with theirs". Cooke recognized the fact that Emerson had redefined mysticism. "His mysticism has broken away from all sectarian and historic limits, and accepted the ground of universal religion. It has planted itself deeply and strongly on an ethical basis, has rejected mere feeling, and has displayed great practical wisdom. As a result, his mysticism is more in sympathy with the tendencies of modern life than that of any of his predecessors" (Cooke 1881, pp. 184-85). In "American Mysticism: The Spiritual Life", an article that appeared in 1894, Cooke saw Emerson in a somewhat different light. Emerson was a mystic all right, but a bit too intellectual. "Had Emerson been more emotional, lived truly the life of the heart, he would have been the greatest of the Mystics" (Cooke 1894, p. 75). Cooke eventually left the ministry to devote himself to scholarship and writing. His book, Unitarianism in America, published by the American Unitarian Association in 1902, was for many years the standard text for a history of the denomination.

By 1894, when the National Conference of Unitarian churches met to draft a new resolution rejecting any authoritative test of faith, the denomination was well on the way to a non-sectarian, post-Christian identity. The three major strands of Unitarian theology at the turn of the twentieth century were liberal Christianity, Transcendentalist idealism, and scientific theism. For some denominational leaders and prominent ministers the Emersonian emphasis on religious experience was the connecting link between the past and the future.

William Wallace Fenn (1862-1932) was another Unitarian minister who left the parish to educate students for the ministry. After serving the First Unitarian Society in Chicago, he joined the faculty at Meadville Theological School, a Unitarian seminary. From there he went to Harvard Divinity School as professor of systematic theology and, later, dean of the faculty. In an 1897 essay on "The Possibilities of Mysticism in Modern Thought", Fenn inquired whether mysticism "has any rightful place in modern thought,- -whether it can naturally arise and thrive in the educated mind of to-day". In a very Emersonian train of thought he concludes that if we believe that we are an integral part of nature and trust to the presence of God within, then we must conclude that God is everywhere in nature, "one life binding all together". The intuitions of the mystic testify to "some direct relation between God and the soul of man". He concludes with a tribute to Emerson's influence:

The great name of Emerson must occur to every American who writes of mysticism...His mysticism was not afterglow, but dawn-flush; and it is the duty and the glory of the present age to reveal in the new world of thought the richness and tenderness of devotion, the fullness of communion with God, which hallowed the old, to follow the shining laws till in their rounding course beauty, music, poetry and grace appear to gladden and sanctify our lives (Fenn 1897, pp. 203, 217).

In 1903 the centennial of Emerson's birth was celebrated with a host of programs in Boston, Cambridge, and Concord. Speaking at a program sponsored by the Unitarian Association held in Boston's Symphony Hall, Harvard President Charles W. Eliot (1834-1926), addressed the topic, "Emerson as Seer". Eliot did not claim that Emerson was a mystic, but he did acknowledge Emerson's influence on religion. Emerson, he said, taught that religion was natural, not supernatural, and believed that "man is guided by the same power that guides beast and flower". God was not a creator set apart from the world, but "the all-informing, all-sustaining soul of the universe". He believed that revelation was natural and continuous. "For Emerson inspiration meant not the rare conveyance of supernatural power to an individual, but the constant incoming into each man of the 'divine soul which also inspires all men'"' (Eliot 1903, pp. 852-53). Eliot came from a prominent Boston Unitarian family and was the father of Samuel Atkins Eliot (1862-1950), who became the longest-serving president of the American Unitarian Association. 
Francis Greenwood Peabody (1847-1936), too, left ministry for a teaching career, first at Antioch College and then at Harvard Divinity School. He is most noted for his close association with the social gospel movement in early twentieth century Protestantism. In an essay on "Mysticism and Modern Life", he wrote-echoing Emerson's "Divinity School Address"- that mysticism is the source of religion and that "to be content with an external, doctrinal, superimposed tradition instead of vital experience, is to live on a left-over faith". He asserted that the "one American contribution to philosophy which by general consent is accepted as original, typical, and permanent [is] the consistent and confident mysticism of Emerson" (Peabody 1914, p. 469). His views on mysticism and his opinion of Emerson were perhaps influenced by an encounter he had with a German professor when he studied abroad as a student. In an undated sermon, "The Church of the Spirit", Peabody recalled that the professor, learning that he was a Unitarian, remarked, "Ah, the Unitarians, they are mystics!" Peabody initially thought the professor's comment strange, but soon changed his mind:

Yet, in fact, his judgment was profoundly and demonstrably true. The Unitarians are mystics. They have contended for theological simplicity, they have contributed to Biblical interpretation; but the representative expressions of their habit of mind are to be sought, not in these fields of learning, but in their witness of the present life of God in the present life of man. It is a line of descent which has been, for the most part, overlooked, even by the eulogists of Unitarianism (Peabody 1925, pp. 12-13).

Earl Morse Wilbur (1866-1956) is most noted for his scholarship and writing on the history of Unitarianism in Europe. His career began as a Unitarian minister. He played a leading role in forming the Pacific Unitarian School for the Ministry, now known as the Starr King School for Religious Leadership. For many years he served as professor and president of the school. In 1916 he authored a pamphlet for the American Unitarian Association entitled, "First Century of the Liberal Movement in American Religion", in which he asked, "Can we find any word to interpret to us the present stage of the movement?" He noted that Francis Peabody had characterized the inner significance of the movement in terms of mysticism. "I have long felt, and have been glad to find others sharing the feeling", Wilbur wrote, "that we have here the best interpretation we have ever had of what the Liberal Movement has come to, and of what it may hope in the future to realize more fully with every added year" (Wilbur 1916, pp. 24-25).

In 1959, Alfred P. Stiernotte (1908-1972) edited a book, Mysticism and the Modern Mind, containing essays on mysticism, some of them written by prominent Unitarian ministers and philosophers. Stiernotte himself was a Unitarian who taught at the Theological School of St. Lawrence University, a Universalist seminary, before taking a position in the philosophy department at Quinnipiac College. In his own contribution to the volume, Stiernotte argued in favor of a dynamic, naturalistic, and humanistic form of mysticism, but with a cosmic dimension. "Emerson's ever-recurring metaphor of man acting 'in accordance with Nature'", he wrote, "is closely related to what we are trying to say. It means his intuition that the potentiality of nature reaches its highest fulfillment in the potency of the human mind" (Stiernotte 1959, p. 188).

Another contributor to the book was John Haynes Holmes (1879-1964), a Unitarian minister who for many years occupied the pulpit at New York's Church of the Messiah, later renamed the Community Church of New York. While warning of the perils of fanaticism, withdrawal, and self-absorption, he found in mysticism "the highest and truest expression of spiritual faith":

Mysticism, in its true estate, is spiritual experience. It is therefore the beating heart of religion.

Reason at its best is the interpretation and formulation of this spiritual experience. Its product is theology.

Theology, like metaphysics, has its uses. One of these uses is not to serve as a substitute for religion. Yet the churches have persistently made this substitution and thereby wrought great ill. 
There are many programs for the recovery of the churches. One assuredly is the recovery of mysticism. To supplant the theologian with the true mystic would save religion (Holmes 1959, pp. 17, 21).

Henry Nelson Wieman (1884-1995) was an ordained Presbyterian minister, but later in life changed his religious affiliation to Unitarianism. For many years he was professor of philosophy and religion at the University of Chicago Divinity School. In his essay, "The Problem of Mysticism", written for Mysticism and the Modern Mind, he wrote, "[Mystical] experiences have been excluded from awareness in great part precisely because the highly refined abstractions of Western culture cannot interpret them in any meaningful way. But cultural conditions have developed of such sort that this mass of data can no longer be excluded". The value of such experiences is that they are transformative. The problem of mysticism arises when mystics claim that the experience gives them knowledge of God as set forth in the Western tradition. "This claim need not cause dispute if it is clearly understood that 'God' so used, is a symbol for a depth and wholeness of Being which no structure of knowledge can compass" (Wieman 1959, pp. 39, 33).

Of all the contributors to the book, Lester Mondale (1904-2003) was the only one who wrote specifically about Emerson's mysticism. Mondale was a Unitarian minister who considered himself a humanist. He was the only person to sign all three Manifestos of the humanist movement, in 1933, 1973, and 2003. He served several Unitarian congregations and at least one Ethical Culture Society. In his essay, "The Practical Mysticism of Ralph Waldo Emerson", Mondale recognized that Emerson's "mysticism was not mystic in the ordinary connotation of the word-the ultimate in seizure and god-apprehension of the adept". It was an experience available and useful to all manner of persons. "Here in a sense was mysticism - not of the trance variety, but more in the form of a worldly daily habit of spectator contemplation which became a lifelong practice. The result was neither the extreme of exultation, a mystic union with oblivion, nor the prolonged spells of mystic aridity, but rather an amazingly sustained serenity that merited the adjective, beatific" (Mondale 1959, pp. 44, 52).

Kenneth L. Patton (1911-1994) was a humanist who ministered to Unitarian and Universalist congregations. He was a prolific writer of poetry, hymns, and readings for worship. In his essay for the volume, "Mysticism and Naturalist Humanism", Patton argued that human beings are creatures of nature. They possess no special faculties that enable them to perceive a spiritual reality beyond the material world. There is a "kind of experience which I would call mystical, and which is perhaps the same quality that others might interpret as spiritual and as providing contact with and knowledge of a realm above the physical, mundane order of everyday life", he wrote. "But do we need to look outside of ourselves and the world about us for an accounting of such states of being? I cannot see why" (Patton 1959, pp. 78, 80).

By the middle of the twentieth century religious humanism was in the ascendency in Unitarian churches. With the merger in 1961 of the Unitarian and the Universalist denominations, once again Emerson was viewed as a bridging figure. In 1975, Jacob Trapp (1899-1992), a Unitarian minister and poet, published an article in the Unitarian Universalist Christian magazine on "Ralph Waldo Emerson: continental divide of American Unitarianism". Trapp indicated that there were two opposing poles in Unitarian Universalism, the Unitarian Christians and the Humanists, "but there is little creative tension between them". He argued that a renewed appreciation of Emerson might bridge the divide. "There has been, and there is, a famine in our churches", Trapp wrote, echoing Emerson's "Divinity School Address", "The world will never unite merely on programs. We need union on the deeper level of the inexpressible, 'of the oneness of our being descending into us from we know not whence.' And in our quest for such union, we as Unitarians can still look to Emerson for inspiration and insights" (Trapp 1975, pp. 37-38).

On the 150th anniversary of Emerson's "Divinity School Address", the journal, Religious Humanism, devoted two issues to Emerson's influence on liberal religion. Most of its contributors were Unitarian Universalist scholars and ministers, eight of whom were featured in these two issues. Paul H. Beattie (1937-1989) was a Unitarian Universalist minister and editor of the journal. “One person is primarily 
responsible for modern Unitarian Universalism", Beattie wrote. "Had he not lived, twentieth-century Unitarian Universalism might possibly never have emerged". This, of course, was Emerson, whom Beattie credited with having pioneered an entirely new perspective for religion in America. Once considered heretical, his ideas were widely accepted among the Unitarians by the end of the nineteenth century. Since then, his writings have encouraged more people to become Unitarian than those of any other historical figure. Beattie described Transcendentalist philosophy as "a pan-spiritualism that allows each person to experience the divine according to the promptings of individual intuition and reason". Emerson was largely responsible for articulating this point of view. "Because what Emerson felt, thought, and wrote was broader than the teaching of any other church or sect in western history, he forced Unitarians and Universalists to outgrow the concepts and forms of traditional religion" (Beattie 1988, pp. 57, 59, 63).

When the Unitarians merged with the Universalists their statement of purposes was vague as to unifying principles, no doubt because of the diversity of Unitarian and Universalist theological opinion at the time. A commission convened shortly after the merger identified six theological positions within the newly formed denomination: liberal Christianity; deism; mystical religion; religious humanism; naturalistic theism, and existentialism (Robinson 1985, p. 175). By the 1980s there was increased diversity with the inclusion of feminist and pagan theologies, leading to an effort to craft a new statement of Unitarian Universalist Principles and Purposes. Once again, Emerson's emphasis on religious experience could be seen in the formulation of the association's statement, adopted in 1985 . Along with the statement of principles was a list of sources from which Unitarian Universalists derive their faith. The first of these sources reads, "direct experience of that transcending mystery and wonder, affirmed in all cultures, which moves us to a renewal of the spirit and an openness to the forces that create and uphold life". It is a line that could have been lifted from Emerson's "Divinity School Address" and reflects the radical reinterpretation of traditional religious categories which is now taken for granted, but when first formulated by Emerson and the Transcendentalists, opened the way to a new understanding of mysticism and spirituality and their role in personal religious life.

As in the case of the sources statement just mentioned, the influence of Emerson and the Transcendentalists has largely been implicit rather than explicit. In recent decades, Unitarian Universalists, like many of their fellow Americans, have expressed a desire for a greater sense of spirituality in their lives. Many have turned to other religious traditions in search of the spirituality they seek: Buddhism, Creation Spirituality, paganism, goddess religion, and native traditions, to name only a few. Both the impulse and the encouragement to draw spiritual nourishment from these traditions are a result of the redefinition of religion and mystical experience wrought by Emerson and the Transcendentalists. And yet contemporary practitioners are largely unaware that there exists a uniquely and authentically Unitarian Universalist spirituality.

Stirred to some degree by the scholarship of literary historians such as David Robinson, Robert Richardson, and Lawrence Buell-themselves Unitarian Universalists—there has been a revival of interest in Emerson and the Transcendentalists among the Unitarian Universalists. In 2003, the Unitarian Universalist Association celebrated the Emerson Bicentennial with a number of programs and publications, and an exhibition that traveled to various places during the year. Speaking at a bicentennial event at Boston's First Church, Robinson acknowledged Emerson's troublesome relationship with Unitarianism. Not only had Emerson broken with historical Christianity but he also criticized the churches. His perceived anti-establishment stance has been a sore spot with defenders of the denomination ever since. Nevertheless, Robinson observed, Emerson has had a continuing influence on the movement by virtue of his emphasis on religious experience.

Transcendentalism was grounded in religious experience; it understood the cosmos as a holistic unity; it taught reverence for the natural world; and it affirmed the human capacity for right action. To begin with, Emerson advocated a religion based on ... a core of undeniable direct experience. The mystical moment, the experience of the holy, the condition of self-transcendence...[pointing] to the phenomenon of the individual being 
brought outside of herself, of being confronted with something awe-inspiring in its nature, that both transcends and includes the self (Robinson 2003).

Finding the old religious terminology inadequate for expressing the nature of ecstatic experience, Emerson formulated new ways of communicating it. Transcendentalism wasn't anything new, Emerson said, but rather "the very oldest of thoughts cast into the mold of these new times" (Emerson 1971-2013, vol. 1, p. 21). The emphasis on religious experience is central to Unitarian Universalism, and Emerson is still regarded as a major figure in Unitarian history. But the nature of religious experience as Emerson described it and the story of its continuing influence within the movement is less well known.

Conflicts of Interest: The author declares no conflict of interest.

\section{References}

Beattie, Paul H. 1988. Unitarian Universalism's Greatest Exponent. Religious Humanism 22: 57-64.

Chai, Leon. 1987. The Romantic Foundations of the American Renaissance. Ithaca: Cornell University Press.

Clarke, James Freeman. 1881. Events and Epochs in Religious History. Cambridge: James R. Osgood and Company.

Cooke, George Willis. 1881. Ralph Waldo Emerson: His Life, Writings, and Philosophy. Boston: James R. Osgood and Company.

Cooke, George Willis. 1894. American Mysticism: The Spiritual Life. Current Literature 15: 75.

Delafield, John. 1847. Mysticism and Its Results: Being an Inquiry into the Uses and Abuses of Secrecy. St. Louis: Edwards \& Bushnell.

Eliot, Charles W. 1903. Emerson as Seer. Atlantic Monthly 91: 844-55.

Emerson, Ralph Waldo. 1960-1982. The Journals and Miscellaneous Notebooks of Ralph Waldo Emerson. Edited by William H. Gilman, Alfred R. Ferguson, George P. Clark and Merrell R. Davis. 16 vols. Cambridge: Harvard University Press.

Emerson, Ralph Waldo. 1961-1972. The Early Lectures of Ralph Waldo Emerson. Edited by Stephen E. Whicher, Robert E. Spiller and Wallace E. Williams. 3 vols. Cambridge: Harvard University Press.

Emerson, Ralph Waldo. 1971-2013. The Collected Works of Ralph Waldo Emerson. Edited by Robert E. Spiller, Ronald A. Bosco, Alfred R. Ferguson, Joseph Slate and Jean Ferguson Carr. 10 vols. Cambridge: Harvard University Press.

Everett, Charles Carroll. 1874. Mysticism. The Unitarian Review and Religious Magazine 1: 5-23.

Fenn, William W. 1897. The Possibilities of Mysticism in the Modern World. The New World: A Quarterly Review of Religion, Ethics and Theology 6: 201-7.

Frothingham, Octavius Brooks. 1861. The Mystics and Their Creed. Christian Examiner 71: 199-229.

Harding, Walter. 1967. Emerson's Library. Charlottesville: University Press of Virginia.

Holmes, John Haynes. 1959. Mysticism. In Mysticism and the Modern Mind. Edited by Alfred P. Stiernotte. New York: Liberal Arts Press.

Irey, Eugene F. n.d. A Concordance to the Collected Essays of Ralph Waldo Emerson. Available online: http: //concordlibrary.org/special-collections/emerson-concordance/ (accessed 20 April 2017).

James, William. 1925. The Varieties of Religious Experience: A Study in Human Nature. New York: Longmans, Green, and Co.

McGinn, Bernard. 2006. The Essential Writings of Christian Mysticism. New York: Modern Library.

Mondale, Lester. 1959. The Practical Mysticism of Ralph Waldo Emerson. In Mysticism and the Modern Mind. Edited by Alfred P. Stiernotte. New York: Liberal Arts Press.

Norris, Kathleen. 1998. Amazing Grace: A Vocabulary of Grace. New York: Riverhead Books.

Patton, Kenneth L. 1959. Mysticism and Naturalistic Humanism. In Mysticism and the Modern Mind. Edited by Alfred P. Stiernotte. New York: Liberal Arts Press.

Peabody, Francis G. 1914. Mysticism and Modern Life. Harvard Theological Review 7: 461-77. [CrossRef]

Peabody Francis, G. 1925. The Church of the Spirit. Cambridge: Andover-Harvard Theological Library.

Quinn, Patrick F. 1950. Emerson and Mysticism. American Literature 21: 397-414. [CrossRef]

Richardson, Robert D., and William James. 2006. The Maelstrom of American Modernism. Boston: Houghton Mifflin Company.

Robinson, David. 1985. The Unitarians and the Universalists. Westport: Greenwood Press. 
Robinson, David. 2003. Emerson: Religion after Transcendentalism. Paper presented at the Emerson Bicentennial Observance at First and Second Church, Boston, MA, USA, May 7.

Schmidt, Leigh Eric. 2003. The Making of Modern 'Mysticism'. Journal of American Academy of Religion 71: $273-302$. [CrossRef]

Schmidt, Leigh. 2005. Restless Souls: The Making of American Spirituality. New York: HarperCollins.

Southey, Robert. 1834. Lives of the British Admirals: With an Introductory View of the Naval History of England. 3 vols. London: Longman.

Stiernotte, Alfred P. 1959. Philosophical Implications of Mysticism. In Mysticism and the Modern Mind. Edited by Alfred P. Stiernotte. New York: Liberal Arts Press.

Trapp, Jacob. 1975. Ralph Waldo Emerson: continental divide of American Unitarianism. Unitarian Universalist Christian 30: 31-38.

Underhill, Evelyn. 1911. Mysticism: A Study in the Nature and Development of Man's Spiritual Consciousness. New York: E.P. Dutton and Company.

Versluis, Arthur. 2014. American Gurus: From Transcendentalism to New Age Religion. New York: Oxford University Press. Ware, Henry, Jr. 1844. The Mystical Element in Religion. In Christian Examiner and Religious Miscellany. Edited by Alvan Lamson and Ezra Stiles Gannett. Boston: Crosby, Nichols, and Co.

Wieman, Henry Nelson. 1959. The Problem of Mysticism. In Mysticism and the Modern Mind. Edited by Alfred P. Stiernotte. New York: Liberal Arts Press.

Wilbur, Earl Morse. 1916. First Century of the Liberal Movement in American Religion. Boston: American Unitarian Association.

(C) 2017 by the author. Licensee MDPI, Basel, Switzerland. This article is an open access article distributed under the terms and conditions of the Creative Commons Attribution (CC BY) license (http:/ / creativecommons.org/licenses/by/4.0/). 